\title{
The Relationship between the Information Technology Skills Acquired by Secretarial Teachers in Nigeria Colleges of Education and Their Utilization of Internet for Effective Teaching
}

\author{
Adeshina, Tunde Joel ${ }^{1, *}$, Udoh, Abasido ${ }^{2}$, Ndomi, Benjamin ${ }^{3} \&$ Aliyu, Muhibeedeen ${ }^{2}$ \\ ${ }^{1}$ Department of Business Education, Federal College of Education, Zaria, Nigeria \\ ${ }^{2}$ Department of Vocational and Technical Education, Ahmadu Bello University, Zaria, Nigeria \\ ${ }^{3}$ Department of Vocational Education, ModiboAdama University of Technology, Yola, Nigeria \\ *Corresponding author: Department of Business Education, Federal College of Education, Zaria, Nigeria \\ Tel: 234-803-614-6596Ｅ-mail: shinatundejoe@yahoo.com
}

Received: February 27, 2013

Accepted: April 7, $2013 \quad$ Online Published: April 21, 2013

doi:10.5430/wje.v3n2p71

URL: http://dx.doi.org/10.5430/wje.v3n2p71

\begin{abstract}
This study established the relationship between the Information Technology skills acquired by Secretarial Teachers in Nigerian Colleges of Education and their utilization of Internet for effective teaching. 250 Secretarial Teachers drawn from 58 Accredited Nigerian Colleges of Education responded to the questionnaire that was divided into 4 parts. The questionnaire was used to obtained information on the respondents' Bio-data and computer use background, Teacher Information Technology Skill Acquisition Competence (TITSC), Teacher Information Technology Skills Usage (TITSU), Teacher Information Technology Internet Knowledge (TITIK), and The extent of usage of Internet information to teach the Secretarial courses. Data were analyzed using descriptive statistics and Pearson Product Moment Correlation Coefficientat 0.01 level of significance. Using Choudhury's Range, there was a moderate positive correlation or relationship between the IT skills of Secretarial Teachers and the ability to use internet to access information for effective teaching. The implication of this result is that, if the secretarial teachers are more competent in their IT skills, then the more will they be enabled to access information from the Internet for effective teaching. In this study it was found that the secretarial teachers were not knowledgeable in the use of some vital and important Internet instructional delivery tools. Secretarial Teachers in the Nigeria Colleges of Education lacked some vital Information Technology skills such as, ability to operate data base, ability to extract relevant information using integrated software packages, ability to extract information using electronic mails and application software, ability to use voice recognition system and ability to operate other different technologies and appreciate their benefits. It was therefore recommended that, National Commission of Colleges of Education should bring together all the secretarial education stakeholders: curriculum experts, the teachers, representatives of ministries and industries; to revisit the existing curriculum. The integration of latest Information Technology practices and the requisite Internet skills which the Secretarial Teachers lack, will reposition Secretarial Studies programme to meet the challenges of an IT driven classroom.
\end{abstract}

Keywords: Information Technology (IT) skills; internet utilization; lecture delivery

\section{Introduction}

Users can search for information about any topic using the Internet. The Internet is used in diverse fields, such as business, entertainment, education, communication, medicine, defence, engineering and sports (Okebukola, 2008). Information Technology has the world's largest broad band which embraces all networks has changed the face of the world we live in. Information Technology enables people to communicate with family, friends and colleagues around the world instantaneously, gain access to global libraries, information resources, and numerous opportunities, hence Information Technology must have brought improvement in the Nigerian educational sector (Adeshina, 2007).

Information Technology has been recognized by the Federal Government of Nigeria as a veritable tool towards sustainable development and global competitiveness. The Federal Government of Nigeria began the implementation 
of the Information Technology policy in April 2001 after the Federal Executive Council approved it by establishing the National Information Technology Development Agency (NITDA), as the implementing body (Emadoye, 2002). In view of this fact, the Information Technology is yet to revolutionize the classroom.

The Nigerian Colleges of Education in Nigeria have been established to provide professionally qualified non-graduate teachers who will teach in the primary and secondary schools of Nigeria. Secretarial Education is one of such courses taught within the domains of the Vocational and Technical Education, particularly in the Business Education programme. Toward satisfying this definition therefore, secretarial/office education incorporates the following courses - Typing, Shorthand, Business Communication, office practice, secretarial duties office management, computer appreciation and application, word processing, principles of Management, Entrepreneurship, and Methods of teaching business subject. These are vocational skills to equip students with and to make them competent in an Information Technology related world of work (Federal College of Education, Zaria Student's Handbook, 2009).

Secretarial Education was designed as a programme in Business Education for Students to opt for by the National Commission for Colleges of Education (NCCE) in 1985 and placed emphasis on Typewriting, Shorthand and Office related disciplines. With the introduction of Information Technology in 2001, Secretarial Education was repositioned. The 2002 review of the Nigerian Certificate of Education (NCE) minimum standards incorporated some major elements of Information Technology into the teaching of secretarial education. Such courses included Computer Appreciation, Information Technology, and Word Processing. The course descriptions include the acquisition of skills on Computer hardware and software, Computer Techniques, Programming Languages, Information Technology Concepts, Word Processing, Electronic Data Application Systems and Electronic Communication systems (NCCE, 2002).

Provisions were made for teachers to acquire Information Technology skills so as to qualify to teach in the entire Business Education Programme, Computer Literacy is a requirement. However, it is not clear whether all the secretarial teachers have the Information Technology skills, hence the need to assess the level of their IT skills and to see how much of it they have been able to use to access information from the Internet for effective teaching delivery and production of IT compliant products. The more the IT skills possessed by Secretarial Teachers, the more the ability to seek for more detailed up-to-date and relevant information that will promote effective teaching delivery and vice versa.

This study, therefore, aims at establishing a relationship between Information Technology Skills of Secretarial Teachers in Nigerian Colleges of Education and their ability to utilize the Internet in teaching the students, with a view to improve classroom teaching.

\section{Objective of the Study}

The objective of this study is to establish the relationship between the Information Technology skills acquired by Secretarial Teachers in Nigerian Colleges of Education and their utilization of Internet for effective teaching.

\section{Research Question}

What Is the relationship between the Information Technology skills acquired by the Secretarial Teachers and their utilization of Internet for effective teaching?

\section{Research Hypothesis}

Null Hypothesis: It was significant at 0.01

There is no significant relationship between the Information Technology skills acquired by secretarial teachers and their utilization of internet for effective teaching.

\section{Methods}

The study used survey design with 250 Secretarial (Business Education) Teachers drawn from 58 accredited Nigerian Colleges of Education. No sampling was done because of the small size of the target population. However, out of the 250 Secretarial Teachers, only 225 Secretarial Teachers responded to the questionnaire that was divided 
into 4 parts. Questionnaire was used to obtained information on the respondents' Bio-data and computer use background, Teacher Information Technology Skill Acquisition Competence (TITSC), Teacher Information Technology Skills Usage (TITSU), Teacher Information Technology Internet Knowledge (TITIK), and The extent of usage of Internet information to teach the Secretarial courses. The items were scored using 4 point scale as follows: Adequately Skilled = 4, Skilled 3, Fairly Skilled =2, Not Skilled =1; Very Well = 4, Well = 3, Fairly Well =2, Not at all $=1$, Very Knowledgeable $=4$, Knowledgeable = 3, Fairly Knowledgeable = 2, Not Knowledgeable $=1$; Very Often $=4$, Often =3, Occasionally =2, Never =1; Very Much =4, Much =3, Little = 2, Not at all =1. The STITB Instrument was validated through pilot study in Kaduna and Zaria Polytechnics using graduates of Secretarial Business Education and whose colleges also run similar secretarial programmes as in the Nigerian Colleges of Education. The reliability coefficient of 0.90 was obtained. The research instruments were administered by the researcher on 250 Secretarial Teachers with the assistance of 12 field assistants, however, only 225 participants returned the instrument duly completed.

\section{Results}

Tables 1 through 10 showed the results. Data were analyzed using simple percentage and Pearson Product Moment Correlation Coefficient (PPMCC).

Analyses of Bio Data:

Educational Qualifications of the Respondents - The responses of the respondents bytheir educational qualifications were presented in Table 1.

Table 1: Percentage of Respondents by Educational Qualifications

\begin{tabular}{lcc}
\hline Qualification & Frequency & Percent \\
\hline Bachelor Degree & 57 & 25.3 \\
Masters Degree & 145 & 64.5 \\
Doctorate Degree & 9 & 4.0 \\
Others & 14 & 6.2 \\
Total & 225 & 100.0 \\
\hline
\end{tabular}

\section{Source: Field Survey, 2011}

Table 1 showed that the Colleges of Education in Nigeria were equipped with qualified post graduate teachers to teach the secretarial Education. This will go a long way to offset any deficiency in curriculum, in textbooks and in equipment.

Ranks of the Respondents - The responses of the respondents by ranks werepresented in Table 2.

Table 2: Percentage of Respondents by Rank

\begin{tabular}{lcc}
\hline Rank & Frequency & Percent \\
\hline Chief Lecturer & 15 & 6.7 \\
Principal Lecturer & 23 & 10.2 \\
Senior Lecturer & 54 & 24.0 \\
Lecturer 1 & 26 & 11.5 \\
Lecturer 2 & 31 & 13.8 \\
Lecturer 3 & 33 & 14.7 \\
Assistant Lecturer & 38 & 16.9 \\
No Rank indicated & 5 & 2.2 \\
Total & 225 & 100.0 \\
\hline
\end{tabular}

\section{Source: Field Survey, 2011}

Table 2 revealed that the Colleges of Education in Nigeria are equipped with qualified teachers that are also well advanced in their teaching experiences as could be seen in their respective ranks. The Colleges of Education were not bottom heavy as there are $52.4 \%$ Senior Academics that can mentor the other $47.6 \%$ for a positive teaching learning processes

Number of Years of Teaching Experience - The responses of the respondents by number ofyears of teaching experience were presented in Table 3. 
Table 3: Percentage of Respondents by Years of Teaching Experience

\begin{tabular}{lcc}
\hline $\begin{array}{l}\text { Teaching Experience } \\
\text { (in Years) }\end{array}$ & Frequency & Percent \\
\hline $1-3$ & 28 & 12.5 \\
$4-6$ & 41 & 18.2 \\
$7-10$ & 45 & 20.0 \\
$11-15$ & 31 & 13.8 \\
Above 15 & 79 & 35.1 \\
Not indicated & 1 & 0.4 \\
Total & 225 & 100.0 \\
\hline
\end{tabular}

\section{Source: Field Survey, 2011}

Table 3 showed that the Colleges of Education in Nigeria are not only equipped with qualified Teachers who had rose to become senior academics, but their years of teaching experience attested for them. These lecturers that have at least four years of teaching experience sum up to $87.1 \%$, who by regulation had their appointments confirmed.

\section{Background on Use of Computer}

Personal Use of computer - The responses of respondents by personal use of computer werepresented in Table 4 .

Table 4: Percentage of Respondents by Personal Use of Computer

\begin{tabular}{lcc}
\hline Personal use of computer & Frequency & Percent \\
\hline I have & 217 & 96.4 \\
I do not have & 8 & 3.6 \\
Total & 225 & 100.0 \\
\hline
\end{tabular}

\section{Source: Field Survey, 2011}

Table 4 showed that 8 teachers had no personal contact with computers while 217 had. This few must do something fast to acquaint themselves with Information and Communication Technology skills before they are declared redundant or unproductive staff.

Number of Years of experience in using computer - Responses of the respondents by number of years of experience using computer were presented in Table 5.

Table 5: Percentage of Respondents by Years of Experience Using Computer

\begin{tabular}{lcc}
\hline $\begin{array}{l}\text { Years of experience } \\
\text { In using computer }\end{array}$ & Frequency & Percent \\
\hline $1-3$ & 58 & 25.8 \\
$4-6$ & 58 & 25.8 \\
Above 6 & 101 & 44.9 \\
No year indicated & 8 & 3.5 \\
Total & 225 & 100.0 \\
\hline
\end{tabular}

\section{Source: Field Survey, 2011}

Table 5 showed the years of experience in using computer by the secretarial teachers. The total of 217 respondents out of the 225 that had been using the computer for an upward of 1 year and above was considered to be adequate. This is because any consistent practical session given to using computer on a daily basis for an upward of one year should bring some degree of perfection.

Computer procurement - The responses of the respondents by who procured computer for them were presented in Table 6.

Table 6: Percentage of Respondents by Computer Procurement

\begin{tabular}{lcc}
\hline $\begin{array}{l}\text { Source of Computer } \\
\text { Procurement }\end{array}$ & Frequency & Percent \\
\hline Employer & 49 & 21.8 \\
Personal & 167 & 74.2 \\
Not indicated & 9 & 4.0 \\
Total & 225 & 100.0 \\
\hline
\end{tabular}

\section{Source: Field Survey, 2011}


Table 6 showed the ability of most of the secretarial teachers to procure computers for themselves which was very commendable. Out of this number, 49 had theirs procured for them by their employers, most probable on loan, which is also a good gesture towards promoting efficiency in teaching and learning, through the use of computer

Reasons for not Using Computer - The responses of respondents by reasons for not using computer were presented in Table 7.

Table 7: Percentage of Respondents by Reasons for Not Using Computer

\begin{tabular}{lcc}
\hline $\begin{array}{l}\text { Reason for Not Using } \\
\text { Computer }\end{array}$ & Frequency & Percent \\
\hline Do not have knowledge to use it & 2 & 0.9 \\
None available & 6 & 2.7 \\
Too expensive & 5 & 2.2 \\
No time & 2 & 0.9 \\
Others & 1 & 0.4 \\
No response & 209 & 92.9 \\
Total & 225 & 100.0 \\
\hline
\end{tabular}

\section{Source: Field Survey, 2011}

Table 7 showed 16 teachers that could not use the computer and their reasons for not using one. 209 teachers did not respond because they were using computer. It is important to note that, whatever was the reason for not using a computer by any teacher in this IT compliant educational sector is no excuse, for such teachers will soon become obsolete in the teaching profession, because they cannot give effective teaching through the use of IT skills. There will be a replacement of those teachers that cannot perform for those who can offer the IT related teaching service.

Previous Training in computer - Responses of respondents by previous training werepresented in Table 8 .

Table 8: Percentage of Respondents by their Previous Computer Training

\begin{tabular}{lcc}
\hline Formal computer training & Frequency & Percent \\
\hline Had previous training & 189 & 84.0 \\
No previous training & 33 & 14.7 \\
No response & 3 & 1.3 \\
Total & 225 & 100.0 \\
\hline
\end{tabular}

\section{Source: Field Survey, 2011}

Table 8 showed something very impressive on the part of these teachers. The result indicated that many of them that had no computer literacy made personal effort to acquire the skills. This effort supported or agreed with the recommendations of Ugwuanyi and Eze (2009), that, teachers are expected to make personal efforts to have their own personal computers and engage private teachers where possible. This will make them become useful in the IT compliant classroom, as they will be able to teach effectively, giving quality information obtained from the internet.

Computer accessibility - The responses of the respondents by computer accessibility werepresented in Table 9 .

Table 9: Percentage of Respondents by Computer Accessibility

\begin{tabular}{lcc}
\hline Computer accessibility & Frequency & Percent \\
\hline Not accessible & 7 & 3.1 \\
Occasionally accessible & 39 & 17.4 \\
Restricted access & 3 & 1.3 \\
Freely accessible & 173 & 76.9 \\
No response & 3 & 1.3 \\
Total & 225 & 100.0 \\
\hline
\end{tabular}

Source: Field Survey, 2011

Table 9 revealed the respondents' computer accessibility. The result was commendable as they had access. It is important to note that there were some Colleges of Education that collaborated with computer sales depot and Information Technology service providers. This partly explained for the improved accessibility of teachers to computer. The learning of Information Technology skills will only be meaningful to the extent that equipment for teaching was available and functional. 
Number of hours using computer per week - The responses of respondents by number of hours they use computer per week were presented in Table 10

Table 10: Percentage of Respondents by Duration of Using Computer per Week

\begin{tabular}{lcc}
\hline $\begin{array}{l}\text { Duration of Using Computer } \\
\text { Per Week (in Hours) }\end{array}$ & Frequency & Percent \\
\hline $1-3$ & 121 & 53.8 \\
$4-6$ & 63 & 28.0 \\
$7-11$ & 19 & 8.4 \\
Above 11 & 16 & 7.1 \\
No response & 6 & 2.7 \\
Total & 225 & 100.0 \\
\hline
\end{tabular}

\section{Source: Field Survey, 2011}

Table 10 revealed a good number of hours per week using computer. This explained increase for mastery of the Information Technology skills. Practice brings about perfection. As the Teachers perfect in their skill acquisition, the students are better for it, as the teacher can give what they have, and accessing information using the Internet also becomes easier, hence an improvement in their teaching.

Table 11: Correlation Analysis of Scores of Information Technology Skills of SecretarialTeachers and their Awareness to use Internet as Instructional Delivery Tool

\begin{tabular}{llllllll}
\hline Variables & & $\mathrm{N}$ & Mean & SD & $\mathrm{R}$ & Remark & \\
\hline IT Skills (X) & & 225 & 2.60 & 0.65 & & \\
$\begin{array}{l}\text { Sec. Teachers } \\
\text { Awareness (Y) Internet }\end{array}$ & usage & 225 & 2.37 & 0.78 & & $\begin{array}{l}\text { Average Positive } \\
\text { Relationship }\end{array}$ \\
\hline
\end{tabular}

\section{Source: Field Survey, 2011}

Table 11 in attempt to answer the research question formulated, showed that the Pearson's Product Moment Correlation Coefficient (r) was 0.54 . This revealed an average positive relationship between the scores in the Information Technology skills of Secretarial Teachers in the Nigerian Colleges of Education and the scores in their awareness to use the Internet as Instructional delivery tool. There is a relationship between the Information Technology skills of Secretarial Teachers in the Nigerian Colleges of Education and their awareness to use the Internet as Instructional delivery tool. The result showed that, as the IT skills increase, their awareness to use Internet as instructional delivery tool is also increasing. If these teachers are exposed to more IT training, their awareness to some other Internet search engines that can be used for instructional delivery will be greatly enhanced.

Table 12: Correlation Analysis of Scores of Information Technology Skills Acquired by theSecretarial Teachers and their Utilization of Internet to Access Information

\begin{tabular}{|c|c|c|c|c|c|}
\hline Variables & $\mathrm{N}$ & Mean & SD & $\mathrm{R}$ & Remark \\
\hline IT Skills (X) & 225 & 2.60 & 0.65 & & \\
\hline & & & & 0.59 & Moderate Positive \\
\hline Sec. Teachers Internet usage $(\mathrm{Y})$ & 225 & 2.59 & 0.76 & & Relationship \\
\hline
\end{tabular}

Source: Field Survey, 2011

In an attempt to still answer the research question formulated for the study, Table 12 indicated that the Pearson's Product Moment Correlation Coefficient (r) was 0.59. This also revealed a moderate positive relationship between the scores in the Information Technology skills of Secretarial Teachers in the Nigerian Colleges of Education and their scores in ability to use the Internet to access Information. There is therefore, a relationship between the Information Technology skills of Secretarial Teachers in the Nigerian Colleges of Education and their ability to use the Internet to access Information. The result here shows that, as moderate as the quality of the IT skills the secretarial teachers have, that is how moderate also their ability to used the Internet for classroom delivery.

The relationship established here indicated that if the quality of classroom delivery must be improved and be made effective as required, teachers will need to be trained or retrained in relevant IT skills they do not possess to build their capacity in order to enable them to access all the Internet search engines for quality information. 
Table 13: Pearson Product Moment Correlation Coefficient between Secretarial Teachers'ICT skills and Ability to Use Internet for Effective Teaching

\begin{tabular}{lcccccr}
\hline Variables & $\mathrm{N}$ & $\overline{\mathrm{x}}$ & $\mathrm{SD}$ & $\mathrm{DF}$ & $\mathrm{R}$ & Decision \\
\hline IT skill competence (X) & 225 & 2.60 & 0.65 & & & \\
Sec. Teachers' Internet usage (Y) & 225 & 2.59 & 0.76 & 189 & $0.586^{* *}$ & $\mathrm{~S}$ \\
\hline
\end{tabular}

** Correlation was significant at 0.01 level

To test the null hypothesis of the study, Table 13 indicated that the Pearson's Product Moment Correlation Coefficient $\mathrm{R}$ was 0.586 . Using Choudhury's Range, there is a moderate positive correlation or relationship between the IT skills of Secretarial Teachers and the ability to use internet to access information for effective teaching. Hence the Null Hypothesis is rejected. The result showed that the correlation coefficient was positive for as the value of the mean score of the IT skills competence of the secretarial teachers increases, so does the mean score of their using Internet for effective teaching at a moderate level. The implication of this result is that, if the secretarial teachers are more competent in their IT skills, then the more will they be enabled to access information from the Internet for effective teaching.

\section{Findings}

In this study it was found that the secretarial teachers were not knowledgeable in the use of some vital and important Internet instructional delivery tools. The established deficiencies of Secretarial teachers as reported in the study, made it difficult for them to use some of the 20 internet skilled areas provided in the study. The teachers were able to use only 11 Internet skilled areas and the 9 Internet skilled areas they were not able to use showed that the more IT skills the teachers possessed, the more the Internet skills they will be able to display to access all the vital and up-date information that guarantees quality and effective classroom delivery. The more the Information at the disposal of the teacher the better informed the teacher is about all the courses within the secretarial education offering and very effective will be the teaching of all the courses.

\section{Discussion}

The study revealed that, secretarial teachers possessed some degree of IT skills; nevertheless they were deficient in some very key requisite and important IT skill area thereby making it difficult for these secretarial teachers to get quality information from the Internet that will support them in giving quality and effective instructional delivery. This in turn will produce competent self reliant products that will also become effective and productive in classroom delivery.

Ikelegbe (2007) supported this assertion that, education in Nigeria today cannot be relevant without effective preparation of new generation of pupils and students to effectively acquire competencies in the use and operation of the new Information Technology (IT) in their professional practices. It is suffice to say therefore, that for these generations of students to acquire these competencies, the teachers must first possess the skills, as it is correct to say, that one cannot give what he does not possess. The teachers must possess the Information Technology skills and they are adequately being utilized before they can impart to the students.Acquisition of the skills is not enough but the utilization that is of great importance.

Information Technology as defined by Ikelegbe (2007) is all the modern systems for processing Information and Communication in data, text, image and voice. If the Secretarial Teacher should demonstrate professional qualities, it is imperative that they must, according to Omeje (2009) not only have the deep rooted knowledge and skills in those IT equipment and operations of automated office facilities... and must effectively teach skills in these areas to their students. Omeje reiterated further that a Secretarial teacher should be able to teach effectively, for instance, IT skills relating to word processing, internet services and facilities, and spreadsheet operating system. Nwaokolo (2000) observed that these would make the secretarial teachers remain relevant in the teaching profession. Jegede (2009) maintained that even were teachers used all of these skills well, there will be need for these teacher to move away from this foundational IT knowledge to a higher level of processes that can be translated to a more efficient learning model for student. The Secretarial teachers will therefore need to move away from this foundational IT knowledge to a higher level of processes that can be translated to a more efficient learning model for student. 
The study showed the resultant effect of the deficiencies of the respondents in those required IT skills, as they could not also perform well in the use of all the Internet search engines to access information for effective teaching. The Introduction of Information Technology into the office has revolutionized every aspect of secretarial function. This is an information age and the secretary is at the centre of distribution and communication of information, therefore, specified IT skills have been judged by Jegede (2009), to be beneficial for educators. Internet has made the whole world a global village and it is very important that secretarial teachers improve, update and be adequately prepared to remedy these areas of deficiencies in order to teach very vital skills involved in internet application for information. Agomuo (2004) asserted that, today's business electronic tools include: e-mail, e-commerce, e-banking, and total office operations, and all these demand that the business teachers should be very knowledgeable and skilled in their uses and application to enable them impart the skills to business students. The findings here also agreed with Moore (2004) that in as much as there are a lot of information on the Internet, it is sometimes hard to find out what you are looking for if you do not know how to use the Internet facilities. Unfortunately, the design of Business Secretarial Education curriculum lies primarily with the category of people who themselves were minimally informed on Internet concepts.

The observed phenomenon is a positive result that shows that the secretarial teachers could not effectively demonstrate skillfulness in IT by searching the Internet to download or upload important information or learning materials useful for effective teaching.No teacher teaches what he/she does not know. Akume (2004) in agreement with this assertion therefore, said, that teachers of Business (secretarial) subjects (ICT inclusive) require a lot of skills and competence if they must impart desired knowledge to the learners. Gbenedio (2007) and Ekpenyong (2002) in Omeje (2009) observed that, many business teachers who have been long in the service may find it difficult to update themselves, a teacher of business (secretarial) education needs to complete his/her preparation for his/her job and keep abreast of the changes in his profession through professional improvement activities.

\section{Conclusion}

In view of the findings, the lack of some basic learning experiences that were needed to adequately equip these teachers with ability to download and upload quality information, because of the lack of these IT skills willincapacitate them in accessing Internet and using some IT facilities to move the frontiers of classroom lesson delivery to an enviable greater height. When Secretarial education teachers in the colleges of education do not know the search engines to utilize to acquire information, the greater will be the difficulty of getting up-to-date relevant information that will meet the need of a classroom that had gone globalized.

\section{Recommendation}

It was therefore recommended that, National Commission of Colleges of Education should bring together all the secretarial education stakeholders: curriculum experts, the teachers, representatives of ministries and industries; to revisit the existing curriculum. The integration of latest Information Technology practices and the requisite Internet skills which the Secretarial Teachers lack, will reposition Secretarial Studies programme to meet the challenges of an IT driven classroom. The teachers will be more informed and current in the knowledge of what IT skills are required to possess to make them relevant and useful in the teaching industry.The consequence isthat, Teachers will be well equipped for effective teaching in an electronic classroom.

\section{References}

Adeshina, T. J. (2007). Essentials of Business Communication. Esonaj Publishers Zaria.

Agomuo, E. E. (2004). Co-operative Efforts to Business Teacher preparation. Business Education Journal, 4(2), 25-36.

Akume, B. C. (2004). In-service Needs of Business Studies Teachers in Secondary Schools Ilorin: in Delta State. Business Education Journal, 4(2), 90-97.

Choudhury, A. (2009). Pearson Product Moment Correlation. Retrieved on April 26 $6^{\text {th }}, 2011$ from Experiment Resources: http://www.experiment-resources.com/pearson-product-moment-correlation.html

Emadoye, J. (2002). Information and Communication Technologies: Impact on Governance, Social, and Economic Development. Paper presented at the workshop and exhibition on windows of investment opportunities in the 
Petroleum, Power and Telecommunication Sectors of Delta State, Nigeria. October.

Federal College of Education, Zaria (2009). Student's Guide/Handbook(4 ${ }^{\text {th }}$ Edition). Zaria, Nigeria.

Ikelegbe, S. (2007). Information and Communication Technologies (ICTs) As tools for Developing Nigeria Educational Sector. Journal of Business Studies and Technology Development (JBSTD), 3(2), 129-136.

Jegede, P.O (2009) Assessment of Nigerian Teacher Educators ICT Training. Issues in informing Science and Information Technology Journal Vol. 6. Retrieved 20 ${ }^{\text {th }}$ October, $2010 \quad$ from http://iisit.org/vol16/11SITV6416-420JEDGE639pdf

Moore, J. (2004). Searching the World Wide Web.Untangle the web to find a wealth of Information. Smart Business Publishers: New York.

National Commission for Colleges of Education, Abuja (2002). Minimum Standards for Nigerian Certificate in Education: Vocational and Technical Education( $3^{\text {rd }}$ Edition).

Nwaokolo, P. O. (2000). Business Education in the $20^{\text {th }}$ Century: Implications for Future Direction. Business Education Journal, 3(3), 216-226.

Okebukola, P. (2008). Education Reforms: Imperative for achieving vision 20-20-20. A paper presented at National Summit on Education on Repositioning Nigeria Educational system for the achievement of the National 20-20-20 vision. Abuja.

Omeje, T.S. (2009). An assessment of Information and Communication Technology (ICT) skills required by secretarial studies teachers in tertiary institutions in Kogi state. Business Education Journal, 7(1), 81-94.

Ugwuanyi, M. O., \& Eze, M. E. (2009). Strategies for Effective Implementation of ICT Driven Curriculum for Secretarial Studies Programme for Secretarial Studies Programme in Nigerian Polytechnics. Business Education Journal, 7(1), 62-69. 